\title{
Revitalizing identity for coastal public space in Nha Trang City
}

\author{
Thi Viet Ha Tran ${ }^{1, *}$ and Thi Bich Ngoc $\mathrm{Le}^{1}$ \\ ${ }^{1}$ University of Architecture Ho Chi Minh City, 196 Pasteur, District 1, Ho Chi Minh City, Vietnam
}

\begin{abstract}
The paper studies the formation and development of coastal public space in Nha Trang city and how its current form has not enhanced the local identity. This was a phenomenon commonly seen in many coast cities in Vietnam. This paper aims to provide a referent design guideline for future design of coastal public space in Nha Trang city. As a part of this effort to return identity to the city, we focused on physical and non-physical elements and their relationship in this specific case, treating them as the framework for this research. Drawing on ethnographic interview and geographic data, we looked closely to the shapes of place's identity, including all related elements.
\end{abstract}

\section{Introduction}

Vietnam (with $3.260 \mathrm{~km}$ of coastal line) has a great number of coast provinces (28 provinces) along the Pacific Ocean with over 160 culturally rich and distinctive coastal towns and cities. Coastal public space is one of elements marking the difference of those cities and towns. In addition, each coastal public space embraces within it traces of the formation and development of its local cultural life and spirit and livelihood which are closely bound with the sea. However, together with the urbanization during the last two decades in Vietnam, the value of place identity or uniqueness has been overlooked that has led to many resembling urban designs. Indeed, coastal public space witnesses community-based communication which is considered to be a feature space of urban coastal communities and one of recognition elements of coastal cities. Moreover, coastal public space is a factor that engages communities and enriches the social life. In order to fully understand this space, it is crucial to investigate seriously both physical and non-physical values from which appropriate designs for the space are derive.

Looking closely to the current condition of coast cities, the loss of identity relates to several factors that has been disregarded for such a long time: (1) similarity in design for cities in general and coastal public space in particular despite of natural distinctiveness and local lifestyle; (2) lack of appreciation and awareness for place identity in the system of Vietnam Regulations for Construction and Design [5]; (3) failure in design and management for a rich public space in terms of activities, space forms and time efficiency.

\footnotetext{
* Corresponding author: tranviethavn2002@yahoo.com
} 


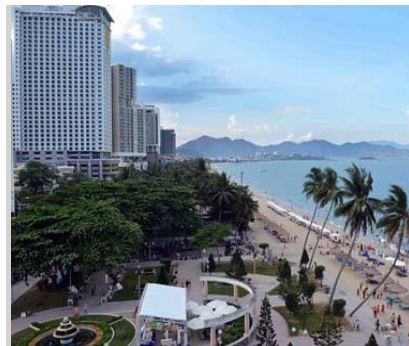

NhaTrang City

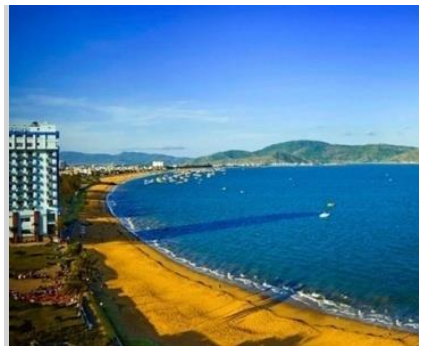

QuyNhơn City

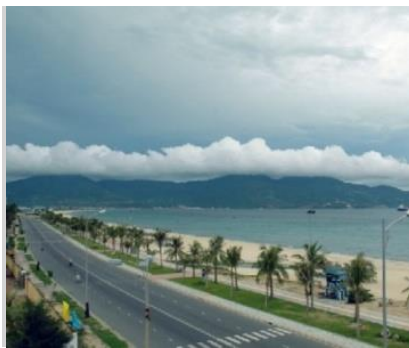

ĐàNẵng City

Fig. 1. Coastal Public Spaces in three major Coast cities of Vietnam (Source: wikimapia.org).

To response to those, we examined both physical and non-physical values of the site, NhaTrang city; as a basis for developing a set of design criteria for place identity maintenance. The following study includes: (1) using user observation to review existing community activities and public spaces; (2) conducting face-to-face interview with users, including preliminary surveys and mass surveys to find "impression" and "expectations" from users; (3) developing a set of design criteria by analyzing those collected data; (4) examining and discussing the applicability of the criteria.

\section{Background}

Despite of the number of research and studies of NhaTrang city, the role of local community in contributing to the local identity has been neglected. For example, in the master study of Nguyen T My Trang, "Urban design of NhaTrang city's main estuary" [6] proposed solutions for spatial connectivity at the estuary area of Cai river in NhaTrang city. The study found that traffic system and spatial connectivity should sever as a principle to exploit the typical values of Cai estuary area. As a result, the study pointed out that longitudinal connectivity has defined the spatial distinctiveness of NhaTrang coastal space, in terms of main functions and landscape. The local community was briefly mentioned as well as coastal public space was not included.

Besides, another study, a Ph.D thesis entitled "Exploiting factors of place to create urban identity - Da Nang city as a research site" by Nguyen Van Chuong [Ошибка! Источник ссылки не найден.] developed a scientific basis for the organization of urban space, including identifying elements from the perspective of physical space and social space. Since then, based on the application of place theory and place mentality to practical conditions in Da Nang, the study provided an orientation in preserving, renovating and developing urban space in the direction of identity. The paper synthesized and developed principles for exploring the value of place on an entire urban scale without resorting to a specific functional area in the characteristic city while each functional region in urban areas would has their own characteristic values.

In addition, there are also a number of article such as, "Planning the Urban Public Space Tourism System," which aims to organize space through the shape of public spaces, therefore to effectively exploit axes, routes and arrays, stripes to express the character of the public square. According to Kevin Lynch [2], the city's image is a part of the city's identity which consists of five elements (path, edge, district, node and landmark. Those elements do not dependently exist but integrate with a rule which derives from the identity of a place. In another attempt, Norberg Schulz [8] outlined main types of vocabulary which are morphology, topology and geometry in order to read and interpret locale through place structure, making this place different, helping define the physical elements that make up the regional identity. Incorporated with this, Yi- Fu Tuan's time element is generalized that the 
place gives us a feeling of time not only in the present but also in the past, where the place is understood and identified for the future.

Another element is the relationship between place and people. People through experiencing a place will recognize the value of place [4]. Therefore, it is necessary to know the location and relationship of users and space. Through comments of many authors, the place associates with the value of the urban environment in terms of natural environment, built environment and human factor $[9,10]$.

\section{Material and methodology}

\subsection{Context analysis}

\subsubsection{History of the formation and development of coastal public space in NhaTrang city}

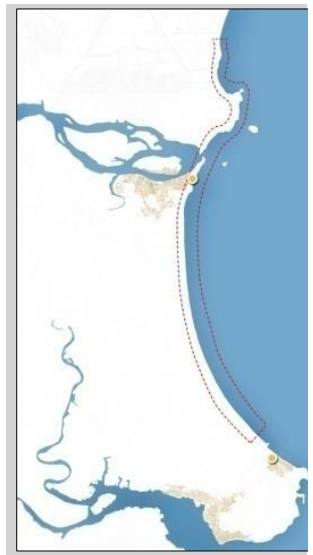

$1820-1890$

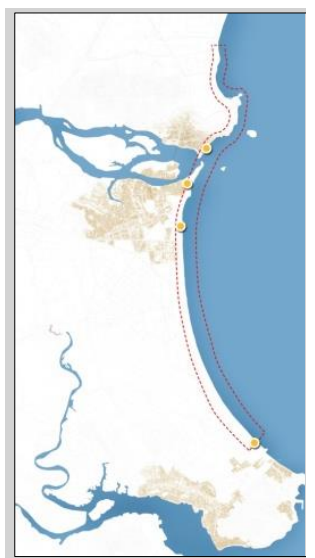

$1891-1930$

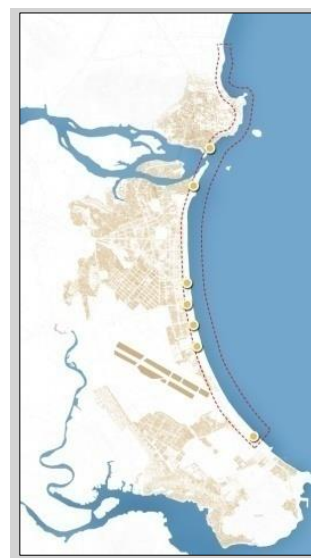

$1931-1975$

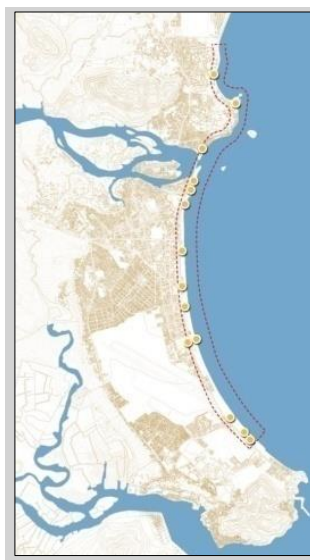

$1976-2016$

Fig. 2. Brief history of coastal public space in NhaTrang city (Source: author).

In 1653, Lord Nguyen Phuc Tan placed Tai Khang palace in NhaTrang city, which is considered as the starting point for the formation of the first residential areas, including Khmer and Kinh people. People lived in the lower parts of the Dinh and Cai river. Since then, the villages were proceeded, but coastal space was still untouched. In the late 19th century, NhaTrang beaches were still mainly occupied by fishing villages. From 1945 to 1999 , NhaTrang city officially became the capital of KhanhHoa province. Coastal areas began to serve public activities informally. Since 1999, there have been changes in traffic and landuse along the beach. The coastal park has been developed to the present. Functional areas along the beach have been gradually filled.

In short, coastal public space has been formed in parallel with urban development. Over many years, coastal public space has brought strong value to the city. However, recently, traditional values of those spaces has lost their original identity.

\subsubsection{Nature Features}

(1) Natural conditions and climate, NhaTrang city is located in the coastal area of South Central Vietnam hence it is influenced by oceanic climate, almost without storms, maintaining a warm temperature all year round. In the summer, the heat is mild and does not 
last as long as other central provinces, which is convenient for outdoor activities. For the wind, the area is often windy which is a significant feature of NhaTrang city.

(2) Topography and soil,thanks to the alluvial plain accreted every year, it is almost unaffected by sea water. The city benefits from tidal flat, white sand and coral reefs in NhaTrang bay. The south is a quite deep - stretching - the sunken seaside. The area is full of rivers, mountains, sea, and rivers. Those topographic values are formed from the tectonic processes of the river deltas and the erosion process.

(3) Hydrology, water levels are directly affected by uneven diurnal tide. The tide lasts from 18-20 days every month. Water level fluctuations are relatively cyclical with a maximum amplitude of $2.4 \mathrm{~m}$. The average amplitude of the tide is $1.2-2 \mathrm{~m}$, the low tide is $0.5 \mathrm{~m}$. The tide regime is typical of the South Central provinces, with relatively clear cycles.

(4) Main ecosystem,marine ecosystem is diverse, including, lagoons, intertidal and estuarine areas, especially coral reefs that create biodiversity with over 350 species.

\subsubsection{Characteristics of habits, customs and practices}

At present, there are 32 ethnic groups living in NhaTrang city, such as, Kinh, Cham, Raglai, Hoa, GieTrieng, Ede, Tay, Nung, Muong ... Each ethnic group has their own way of life, providing the area much potential for community life. Of which, Kinh people is account for 95.3\%. Previously, when commercial activities was not so popular, the major livelihood of the citizens was associated with fishing. The customs of fishermen such as Ruoc Ca Ong parade, Cau Ngu festival, hay ThápBà festival.... are cultural activities become highlights in the spiritual life of the citizens and taken place in coastal public space. In addition, there are other daily activities such as sight seeing, swimming, water-skiing, etc. However, most of the activities are unplanned and managed.

\subsubsection{Physical elements}

In order to examine identical physical elements for this study site, analyzing five following layers of the current settlement is necessary. Underlying topography: The terrain is rich in forms due to different geographical structure which was formed by the deposition of sediment and runoff, creating landscape features, including mountains, bays, sandy beaches, mudflats, etc. Natural system (Water surface and vegetation): In order to suit to brackish environment and sea breeze, coniferous trees are commonly found.

Public linkage system (Type of transportation and street form, public space linkage): there are two main axes, one lies parallel to the coast line and other head toward the sea. There are also several main streets connecting to central square. The strip of land next to the beach gives space for public spaces of the city. Block - Lot form: most of buildings are public with beach front and high density. Components constructing pubic space: contains public services for beach activities such as toilet, fresh water shower, café, etc. connecting directly with the beach.

\subsection{Reseach Methodology}

\subsubsection{Data collection}

Historical method was used to learn and understand the process of formation and development of the site, in order to find out the nature of movement, the trend of development of the area [7]. This method is done by collecting layers of information and historical maps, then looking for population fluctuation by the time. Besides, studying history documents of 
NhaTrang city's development added significantly to our overall understanding.

Observation method was also used for the next step - to identify areas with more concentrated activities and related physical elements. As a result, the initial data could serve as a source for the following steps. At the site, a team of investigators monitored alternately and constantly the number of people present in the study area (Table 1). Equipment for observation record such as cameras was also used. The grid for mapping was the grid of $1 \mathrm{~m}$ $\mathrm{x} 1 \mathrm{~m}$ to pinpoint the exact location of the largest gathering group, zoning activity, marking activity by time and day of the day from time to time in the study area. The number of days monitored included week days and weekends. Here, identified physical elements that made up area of activities were identified. Next, based on the characteristics of the areas, and the concentration of people here, we selected seven areas to operate questionnaires and face-toface interviews.

Table 1. Physical elements.

\begin{tabular}{|c|c|c|c|c|c|c|c|}
\hline \multirow{2}{*}{$\begin{array}{l}\text { Area } \\
\text { code }\end{array}$} & \multirow[b]{2}{*}{ Survey area } & \multirow{2}{*}{$\begin{array}{l}\text { Number of } \\
\text { users observed } \\
\text { during a day }\end{array}$} & \multicolumn{4}{|c|}{ Physical elements } & \multirow{2}{*}{$\begin{array}{l}\text { Area } \\
\text { selected for } \\
\text { the study }\end{array}$} \\
\hline & & & $\begin{array}{l}\text { Distance } \\
\text { to the city } \\
\text { center }\end{array}$ & $\begin{array}{l}\text { Surrounding } \\
\text { function }\end{array}$ & $\begin{array}{l}\text { Landmar } \\
\mathrm{k} \\
\text { building }\end{array}$ & $\begin{array}{l}\text { Characteristics } \\
\text { of the area }\end{array}$ & \\
\hline $1 \mathrm{~A}$ & $\begin{array}{l}\text { Nothern area of } \\
\text { HònChồng }\end{array}$ & Few people & \multirow[t]{2}{*}{$\begin{array}{l}\text { About } \\
5 \mathrm{~km}\end{array}$} & \multirow[t]{2}{*}{ Resident } & \multirow{2}{*}{$\begin{array}{l}\text { Area } \\
\text { without } \\
\text { boundary }\end{array}$} & \multirow[t]{2}{*}{$\begin{array}{l}\text { Free } \\
\text { accessibility }\end{array}$} & \multirow[t]{2}{*}{$\begin{array}{l}\text { Not } \\
\text { selected }\end{array}$} \\
\hline 1B & HònChồng & $\begin{array}{l}\text { Few people at } \\
\text { certain time } \\
\text { during the day }\end{array}$ & & & & & \\
\hline $1 \mathrm{C}$ & $\begin{array}{l}\text { Park in the north } \\
\text { TrầnPhú Bridge }\end{array}$ & $\begin{array}{l}\text { Few people at } \\
\text { certain time }\end{array}$ & $\begin{array}{l}\text { About } \\
4 \mathrm{~km}\end{array}$ & \multicolumn{2}{|c|}{$\begin{array}{l}\text { Town houses with } \\
\text { commercial function on the } \\
\text { ground floor }\end{array}$} & \multirow[t]{2}{*}{$\begin{array}{l}\text { Good } \\
\text { accessibility }\end{array}$} & Selected \\
\hline 2 & $\begin{array}{l}\text { AlexandreYersin } \\
\text { Park + volleyball } \\
\text { court }\end{array}$ & $\begin{array}{l}\text { Few people at } \\
\text { certain time }\end{array}$ & \multirow[t]{2}{*}{$\begin{array}{l}\text { About } \\
2 \mathrm{~km}\end{array}$} & \multicolumn{2}{|c|}{$\begin{array}{l}\text { Apt building } \\
\text { commercial podium }\end{array}$} & & Selected \\
\hline $3 \mathrm{~A}$ & $\begin{array}{l}\text { Park in front of } \\
\text { Yến Phi Park }\end{array}$ & $\begin{array}{l}\text { Few people at } \\
\text { certain time }\end{array}$ & & \multicolumn{2}{|c|}{$\begin{array}{l}\text { Non-commercial public } \\
\text { building at city level }\end{array}$} & $\begin{array}{l}\text { Free } \\
\text { accessibility } \\
\text { without limit }\end{array}$ & $\begin{array}{l}\text { Not } \\
\text { selected }\end{array}$ \\
\hline 3B & $\begin{array}{lr}\text { Beachfront land } \\
\text { along } & \text { Sunrise } \\
\text { and } & \text { Novotel } \\
\text { Hotel } & \\
\end{array}$ & \multicolumn{5}{|c|}{ Private properties with accessibility limitation } & $\begin{array}{l}\text { Not } \\
\text { applicable }\end{array}$ \\
\hline $3 \mathrm{C}$ & $\begin{array}{l}\text { Park along the } \\
\text { beach with } \\
\text { commercial } \\
\text { kiosks }\end{array}$ & $\begin{array}{l}\text { Few people at } \\
\text { certain time }\end{array}$ & $\begin{array}{l}\text { The edge } \\
\text { of the } \\
\text { city } \\
\text { center }\end{array}$ & $\begin{array}{l}\text { Large scale } \\
\text { commercial } \\
\text { building }\end{array}$ & $\begin{array}{l}\text { Harmoni } \\
\text { ous space }\end{array}$ & $\begin{array}{l}\text { Free } \\
\text { accessibility }\end{array}$ & Selected \\
\hline $3 \mathrm{D}$ & $\begin{array}{l}\text { Park along the } \\
\text { beach }\end{array}$ & Few people & $\begin{array}{l}\text { The edge } \\
\text { of the } \\
\text { city } \\
\text { center }\end{array}$ & \multicolumn{2}{|c|}{$\begin{array}{l}\text { Medium scale commercial } \\
\text { building with high building } \\
\text { density }\end{array}$} & $\begin{array}{l}\text { Free } \\
\text { accessibility }\end{array}$ & $\begin{array}{l}\text { Not } \\
\text { selected }\end{array}$ \\
\hline $4 \mathrm{~A}$ & $\begin{array}{l}\text { Area around } \\
\text { BốnMùa cafe }\end{array}$ & \multirow[t]{3}{*}{$\begin{array}{l}\text { People at all } \\
\text { time }\end{array}$} & $\begin{array}{l}\text { In the } \\
\text { city } \\
\text { center }\end{array}$ & $\begin{array}{l}\text { Large scale } \\
\text { commercial } \\
\text { building }\end{array}$ & \begin{tabular}{|l} 
Existence \\
of \\
distinctiv \\
e space \\
\end{tabular} & $\begin{array}{l}\text { Free } \\
\text { accessibility }\end{array}$ & Selected \\
\hline 4B & $\begin{array}{l}\text { TrầmHương } \\
\text { Tower area }-2 / 4 \\
\text { square }\end{array}$ & & \multicolumn{4}{|c|}{$\begin{array}{l}\text { Located at the core of the city center, consists of landmark } \\
\text { buildings and large scale commercial buildings with high value } \\
\text { and significant architecture. }\end{array}$} & Selected \\
\hline $4 \mathrm{C}$ & Southern park & & $\begin{array}{l}\text { In the } \\
\text { city } \\
\text { center }\end{array}$ & $\begin{array}{l}\text { Large scale } \\
\text { commercial } \\
\text { building }\end{array}$ & $\begin{array}{l}\text { Harmoni } \\
\text { ous space }\end{array}$ & $\begin{array}{l}\text { Free } \\
\text { accessibility }\end{array}$ & Selected \\
\hline 5 & $\begin{array}{l}\text { Park along the } \\
\text { beach }\end{array}$ & $\begin{array}{l}\text { Few people at } \\
\text { certain time }\end{array}$ & Far & \multicolumn{2}{|c|}{$\begin{array}{l}\text { Town houses with commercial } \\
\text { function on the ground floor }\end{array}$} & $\begin{array}{l}\text { Good } \\
\text { accessibility }\end{array}$ & $\begin{array}{l}\text { Not } \\
\text { selected }\end{array}$ \\
\hline 6 & $\begin{array}{l}\text { Buildings: } \\
\text { Louisiane, } \\
\text { PhùĐống, Ana } \\
\text { Mandara } \\
\end{array}$ & \multicolumn{5}{|c|}{ Not suitable for outdoor public space as accessibility is limited } & $\begin{array}{l}\text { Not } \\
\text { applicable }\end{array}$ \\
\hline $7 \mathrm{~A}$ & Area for events & $\begin{array}{l}\text { Few people at } \\
\text { certain time }\end{array}$ & Far & \multicolumn{2}{|l|}{ Town houses } & \multirow[t]{2}{*}{$\begin{array}{l}\text { Free } \\
\text { accessibility }\end{array}$} & $\begin{array}{l}\text { Not } \\
\text { selected }\end{array}$ \\
\hline 7B & BạchĐằng Park & $\begin{array}{l}\text { People at } \\
\text { certain time }\end{array}$ & Far & $\begin{array}{l}\text { Town houses } \\
\text { with commercial } \\
\text { function on the } \\
\text { ground floor }\end{array}$ & $\begin{array}{l}\text { Without } \\
\text { landmark }\end{array}$ & & Selected \\
\hline
\end{tabular}




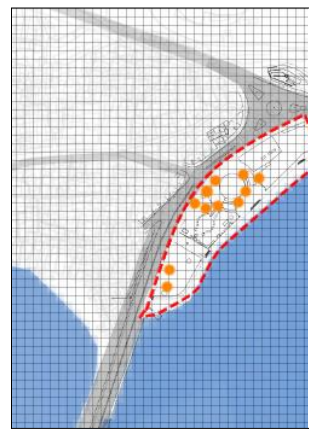

Area 1C

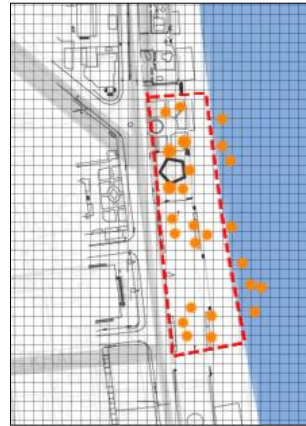

Area 4B

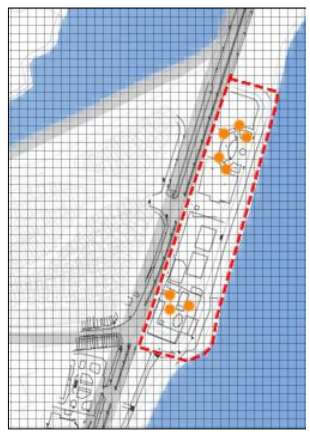

Area 2

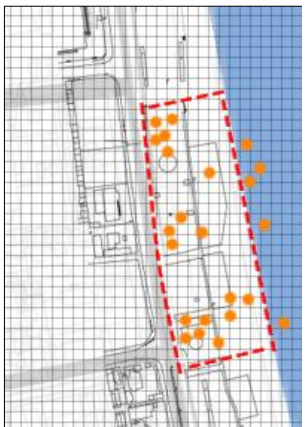

Area 4C

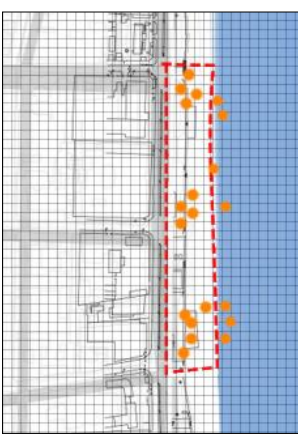

Area3C

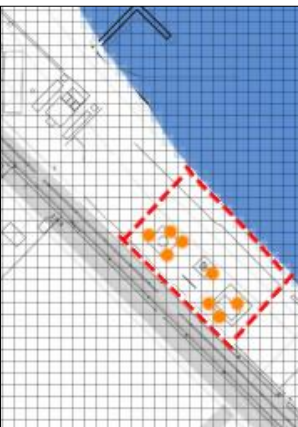

Area 7B

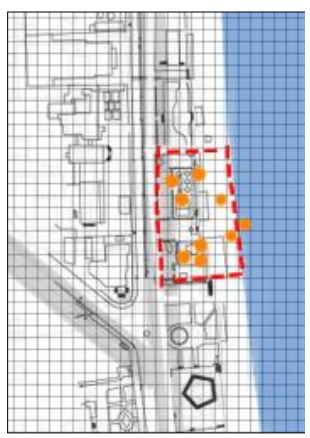

Area4A

Note:

- Crowded nodes

Fig. 3. The results drawn from observation method - 07 selected areas for conducting the in-depth survey (Source: author).

Survey methods was applied on the selected areas to collect data and documents related to the research. This research included interviewing and collecting comments (in both pilot and field surveys) from users in those public areas. The research was conducted at coastal public space in NhaTrang city on sunny days.

Table 2. Objectives.

\begin{tabular}{|c|c|c|c|}
\hline \multirow[t]{2}{*}{ Objectives } & \multirow[t]{2}{*}{ Require data } & \multicolumn{2}{|c|}{ Input source } \\
\hline & & Initial investigation & $\begin{array}{l}\text { Practical investigation } \\
\end{array}$ \\
\hline \multirow{2}{*}{$\begin{array}{l}\text { Relationship of } \\
\text { activities and } \\
\text { physical elements } \\
\text { in the space }\end{array}$} & $\begin{array}{l}\text { Identification levels of } \\
\text { user concentration } \\
\text { within the space }\end{array}$ & $\begin{array}{l}\text { Observation - Note taking with } \\
\text { time sequence }\end{array}$ & \\
\hline & $\begin{array}{l}\text { Relationship of user } \\
\text { concentration and local } \\
\text { facilities }\end{array}$ & $\begin{array}{l}\text { Review from: books, magazines... } \\
\text { Observation - Note taking (diary } \\
\text { with photos...) }\end{array}$ & $\begin{array}{l}\text { Double Observation - Note taking } \\
\text { (diary with photos...) } \\
\text { Interview users }\end{array}$ \\
\hline $\begin{array}{l}\text { The identity of the } \\
\text { space }\end{array}$ & $\begin{array}{l}\text { Impression about the } \\
\text { space includes: first } \\
\text { impression, } \quad \text { deep } \\
\text { impression and } \\
\text { impression on details ... }\end{array}$ & $\begin{array}{l}\text { Review from: books, magazines... } \\
\text { Observation - Note taking (diary } \\
\text { with photos...) }\end{array}$ & $\begin{array}{l}\text { Observation - Note taking (diary with } \\
\text { photos...) } \\
\text { Interview users (sketching and } \\
\text { questionnaires...) }\end{array}$ \\
\hline
\end{tabular}

\subsubsection{Data analysis}

Statistics method - SPSS 20.0 software was applied to outline the usage of coastal public space to find out specific rules of user needs and activities. In addition, another information 
was also involved to measure, compare, and evaluate the extent of the response of space based on community activities in the area. Then, it was possible to classify groups of activities by applying integrated analytical method.

\section{Results}

\subsection{Identify the value of place in coastal public space}

First of all, identification of the identity must be based on visual elements and characteristics of the area. This identification should be based on a system of relationships between elements in in comparison with the present context.

Coastal public space is considered a highlight feature shown in site location, natural values (formed by terrain, water, and sky) and built environment. Those are visible elements that directly affect human perception. In addition, through activities of local people, from daily activities to periodic festivals, though intangible values are not clearly defined in terms of boundaries and constantly changing images, they have brought to the community and the place an outstanding atmosphere and have reflected the indispensable needs of outdoor public spaces in the city. Moreover, the identification of the social factors should pay more attention to cultural-historical factors that are strongly connected to today. These factors include both local people and their activities. Roles of communities, susch as, identify intangible value through communication and neighborhood relationships, greetings to relatives, through social relationships created by age, occupation, lifestyle.

Social activities of citizens are identified through history, architectural heritages or and living habits (such as avoiding fish tail cutting, not turning fish when eating, drawing eyes on the boat bow, ...), beliefs (worship of Ca Ong), festivals (Nghinh Ong parade for good weather), ... these activities have lasted till today as a link between the history and society and a pride of the local people.

Identify factors that forming the identity of coastal public space in NhaTrang city were drawn from analyzing the natural elements, physical and non-material elements through documentary sources, observation and investigation methods.

Table 3. Characteristics

\begin{tabular}{|c|c|c|c|c|}
\hline \multicolumn{2}{|c|}{ Elements } & Characteristics & Changeability & Effects on \\
\hline \multirow{4}{*}{$\begin{array}{l}\text { Natural } \\
\text { Environment }\end{array}$} & $\begin{array}{l}\text { Topography and } \\
\text { soil }\end{array}$ & Mountains-sea-islands & Unchangeable & \multirow{4}{*}{$\begin{array}{l}\text { Having major } \\
\text { effects on the } \\
\text { area and one } \\
\text { of important } \\
\text { elements } \\
\text { forming the } \\
\text { identity. }\end{array}$} \\
\hline & $\begin{array}{l}\text { Weather, climate, } \\
\text { cycle of disasters }\end{array}$ & $\begin{array}{lll}\text { hot all year round and } \\
\text { small number } & \text { of } \\
\text { disasters } & & \end{array}$ & \multirow{3}{*}{$\begin{array}{l}\text { Changes have } \\
\text { been noticeable } \\
\text { during recent } \\
\text { yeas }\end{array}$} & \\
\hline & $\begin{array}{l}\text { Hydrological } \\
\text { conditions: water } \\
\text { edge, submerged } \\
\text { area, saline } \\
\text { intrusion, ... }\end{array}$ & Unstable diurnal tides & & \\
\hline & Ecology system & $\begin{array}{l}\text { Diverse, including many } \\
\text { coral reefs }\end{array}$ & & \\
\hline \multirow{2}{*}{$\begin{array}{l}\text { Non- } \\
\text { physical } \\
\text { elements }\end{array}$} & $\begin{array}{l}\text { Diversity of } \\
\text { population }\end{array}$ & $\begin{array}{l}\text { Kinh people takes the } \\
\text { majority, then Khmer } \\
\text { people }\end{array}$ & \multirow{2}{*}{$\begin{array}{l}\text { Slow changes } \\
\text { but they have } \\
\text { been noticeable } \\
\text { during recent } \\
\text { yeas }\end{array}$} & \multirow{2}{*}{$\begin{array}{l}\text { Affected by } \\
\text { the Kinh and } \\
\text { Khmer } \\
\text { cultures with } \\
\text { many } \\
\text { traditional }\end{array}$} \\
\hline & $\begin{array}{l}\text { Cultural customs } \\
\text { of communities }\end{array}$ & $\begin{array}{l}\text { Maintenance of customs } \\
\text { of coastal communities }\end{array}$ & & \\
\hline
\end{tabular}




\begin{tabular}{|c|c|c|c|c|}
\hline & & & & festivals \\
\hline & Local economy & $\begin{array}{l}\text { Main source of economy } \\
\text { is from tourism }\end{array}$ & Rapid change & \multirow{2}{*}{$\begin{array}{l}\text { Affect } \\
\text { activities of } \\
\text { space users }\end{array}$} \\
\hline & Daily activities & $\begin{array}{l}\text { High potential for } \\
\text { international integration }\end{array}$ & Rapid change & \\
\hline \multirow{6}{*}{$\begin{array}{l}\text { Physical } \\
\text { elements }\end{array}$} & Morphology & $\begin{array}{l}\text { Changed according to } \\
\text { development of area }\end{array}$ & $\begin{array}{ll}\begin{array}{l}\text { Very } \\
\text { change }\end{array} & \text { small } \\
\text { chang }\end{array}$ & \multirow{4}{*}{$\begin{array}{l}\text { Strongly } \\
\text { impact the } \\
\text { vision of the } \\
\text { area }\end{array}$} \\
\hline & Street system & Axes heading to the sea & $\begin{array}{l}\text { Very small } \\
\text { change }\end{array}$ & \\
\hline & $\begin{array}{l}\text { Beachfront } \\
\text { block/ lot forms }\end{array}$ & $\begin{array}{l}\text { Variety in scale regarding } \\
\text { building function }\end{array}$ & Small change & \\
\hline & Building form & $\begin{array}{l}\text { Depend on culture, } \\
\text { aesthetic and economy }\end{array}$ & Frequent change & \\
\hline & $\begin{array}{ll}\text { Facilities } & \text { in } \\
\text { public space } & \end{array}$ & $\begin{array}{l}\text { Urban facilities serving } \\
\text { current activities }\end{array}$ & Frequent change & $\begin{array}{l}\text { Affect on } \\
\text { small spaces }\end{array}$ \\
\hline & $\begin{array}{l}\text { Natural } \\
\text { landscape }\end{array}$ & & Small change & $\begin{array}{l}\text { Create } \\
\text { identity on } \\
\text { larger scale }\end{array}$ \\
\hline
\end{tabular}

\subsection{Revitalizing identity of coastal public space in NhaTrang city}

Defining and revitalizing the identity of coastal public space in NhaTrang city are approached through three factors: physical factors, non-physical factors and natural landscape. Among three, physical factors and landscape are seen as a whole in looking for design and management solutions. After all, we can conserve and develop non-physical values. The followings are suggestions both in terms of physical factors: (1) location, (2) natural landscape and (3) built environment; and non-physical factors. Those suggesstions intend to enhance local characteristicsand user's experience.

Table 4. From physical perspective.

\begin{tabular}{|c|c|c|}
\hline Criteria & Principles & Solutions \\
\hline \multirow[t]{4}{*}{$\begin{array}{l}\text { Exploiting } \\
\text { locality }\end{array}$} & \multirow[t]{4}{*}{$\begin{array}{l}\text { Exploiting } \\
\text { Topography }\end{array}$} & $\begin{array}{l}\text { Locating areas with valuable landscape and maintaining these } \\
\text { natural features }\end{array}$ \\
\hline & & Protecting the visibility to natural landmarks and the beach front \\
\hline & & $\begin{array}{l}\text { Enhance the visibility to prominent elements such as mountains } \\
\text { and sea }\end{array}$ \\
\hline & & $\begin{array}{l}\text { Creating visual corridors by connecting the city and coastal } \\
\text { public space by sea heading street system }\end{array}$ \\
\hline \multirow{5}{*}{$\begin{array}{l}\text { Exploiting } \\
\text { natural } \\
\text { elements }\end{array}$} & \multirow{3}{*}{$\begin{array}{l}\text { Exploiting } \\
\text { water surface }\end{array}$} & Maintaining natural value of water surface \\
\hline & & $\begin{array}{l}\text { Exploiting the splitting characteristics of water currents (rivers, } \\
\text { seas...) }\end{array}$ \\
\hline & & Exploiting reflection characteristic of water surface \\
\hline & \multirow[t]{2}{*}{$\begin{array}{l}\text { Exploiting the } \\
\text { sky }\end{array}$} & $\begin{array}{l}\text { Making use of colors of the nature: blue of the sea, green of } \\
\text { leaves, yellow of sand, brown of mountains, white/ blue of the } \\
\text { sky }\end{array}$ \\
\hline & & Regulating solid and void of building surface, height, materials, \\
\hline \multirow{5}{*}{$\begin{array}{l}\text { Exploiting } \\
\text { built } \\
\text { environment }\end{array}$} & \multirow{5}{*}{$\begin{array}{l}\text { Creating } \\
\text { significant } \\
\text { spaces }\end{array}$} & Creating identical design \\
\hline & & Regulating planning and architecture design \\
\hline & & $\begin{array}{l}\text { Forming small and cozy spaces which are suitable to eastern } \\
\text { culture }\end{array}$ \\
\hline & & Designing architectural solutions supporting landscape \\
\hline & & Trees play an important role in creating a green corridor \\
\hline
\end{tabular}


Table 5. From non-physical perspective.

\begin{tabular}{|l|l|l|}
\hline Criteria & \multicolumn{1}{|c|}{ Principles } & \multicolumn{1}{c|}{ Solutions } \\
\hline $\begin{array}{l}\text { Keeping } \\
\text { local } \\
\text { lifestyle }\end{array}$ & $\begin{array}{l}\text { Enhancing } \\
\text { religious activities }\end{array}$ & $\begin{array}{l}\text { Preserving and enhancing spaces for cultural and spiritual } \\
\text { practices including religious monuments, beach, water surface }\end{array}$ \\
\cline { 2 - 3 } & Enhancingfestivals & $\begin{array}{l}\text { Enhancing local habits of coastal community } \\
\text { Organizing periodic activities according to the characteristics of } \\
\text { each population group. }\end{array}$ \\
\cline { 2 - 3 } & $\begin{array}{l}\text { Promoting current } \\
\text { activities }\end{array}$ & $\begin{array}{l}\text { Developing programs in combination with other cultural } \\
\text { activities }\end{array}$ \\
\hline
\end{tabular}

\section{Discussions}

Identifying values and proposing solutions for coastal public space have added to the field of research an assessment of the ability to reconcile protection and exploitation of natural resources. However, besides the development of the city, there are many issues that need to be discussed in the framework of the study.

NhaTrang city is a fast-growing urban area.According to the policy of developing tourism into a green industry, the expansion of tourism trade and urban development towards internationalization agree with the international integration tendency. Besides, an area with strong identity will always attract many people. As a result, the development of tourism has led to foreign disturbance to the local. Therefore, maintaining identity seems to be more difficult and this is a conflict between conservation and development.

Maintaining and enhancing local identity will bring great values to the city. However, there will be other contradictions in the use, exploitation and preservation of this space. These conflicts can be seen as: (1) inconsistencies arising from unclear ambition between levels of government, such as the exploitation of tourism and the protection of the natural landscape of the coast. (2) Conflicts between preserving identity and achieving profit goals. Allowing investment projects to over-exploit existing conditions as well as infrastructure leads to conflicting interests between identity and economic gain at the pace of fast urban development. (3) Conflicts between individual group interests and community interests since in order to make a living and prosperity, personal benefits may conflict with the public interest, causing aesthetics for urban space.

Thus, the followings are our key considerations: (1) in this work, people understand well the characteristics of their city for appropriate behaviors; governmental departments and agencies need to participate actively in organizing festivals such as Nghinh Ong parade or festival at Ponaga tower ( those are typical local architecture through time).... (2) All efforts mentioned above must be implemented with co-operation in planning, design, marketing and organizing in order to educate local communities for saving local culture (3) the preservation and maintenance of regional identity must be made quickly but also should not interfere harshly with the existing spaces.

\section{Conclusions}

For over 300 years of development, coastal public spaces have formed and created distinct values for coast cities. The identity here is a harmonious synthesis of natural values, human beings and built environment. Establishing regulations that cover both physical and nonmaterial matters will contribute to the recovery of inherent values, which have been vanished gradually.

In addition, the application of those criteria should be more flexible.The importance of each element may vary due to specific context, this effort will help to add more values and maintain the tradition for future generations. 
Departments and institutions such as urban management department, planning institute, and design institute can use this study as a reference material to make appropriate regulations for each area in the design field.

\section{Acknowledgements}

We would like to thank to the community at the research site for providing invaluable information, which was a source of reference and research input. Agencies such as Department of Urban Management, planning institute and design institute can use as reference material to make appropriate regulations for each area in the design.

We also would like to send sincere thanks to Ho Chi Minh City University of Architecture for facilitating and enabling the publication of this paper.

\section{References}

1. J. Gelh, Life between buildings: using public space (Van Nostrand Reinhold, New York, 2002)

2. D. Lynch, The Image of the City (MIT Press, Cambridge, 1960)

3. N. Mạnh Thu, Elements for creating urban identity, Vietnam Architecture Magazine (2008)

4. NhaTrang city Past and Present (Đa Nang Press, 2007)

5. Ministry of Construction, Decision on the release of: National Technical Regulation No 04/2008/QĐ-BXD (2008)

6. N. Thi My Trang, Urban design for estuary are in NhaTrang city, Master thesis (University of Architecture Ho Chi Minh City, Vietnam, 2012)

7. R. Oldenburg, The great good place (Da capo Press, Philadelphia, 2005)

8. S. Norberg, The Concept of Dwelling-On the way to figurative architecture (New York, Electa/Rizzoli, 1985)

9. T.Thi Viet Ha, Creatingcoastal public space-NhaTrang city, Ph.D thesis (University of Architecture Ho Chi Minh City, Vietnam, 2017)

10. V.Q. Truong, Planning for public space system of coastal tourism cities, Construction planning, 74 (2015)

11. Y. Tuan, Space and Place: The perspective of experience (University of Minnesota Press, 2001) 